\title{
O- Irrigation management of muskmelon with tensiometry
}

Márcio José de Santana ${ }^{1}$

Guilherme de Almeida Bocate ${ }^{2}$

Murilo Augusto Sgobi3

Taynara Tuany Borges Valeriano 4

Stefany Silva de Souza 5

\section{Abstract}

The production and consumption of muskmelon have been increasing (MELO et al., 2014), thus, information on techniques for higher field productions are necessary. The experiment described in the present work was conducted in the IFTM, Uberaba, State of Minas Gerais, Brazil, aiming to evaluate the muskmelon yield under different soil water tensions. A randomized block experimental design was used with five treatments (soil water tensions of 10, 20,30, 40 and $50 \mathrm{kPa}$ ) and four replications (plots of two rows of 14 plants). Two harvests were carried out and the fruit yield, stem diameter, number of fruits per plant and efficiency of water use were evaluated. Irrigation was performed with a drip irrigation system and managed with tensiometry. The cultivar Bonus n.2 was used with spacing of $1.0 \times 0.6 \mathrm{~m}$. The data of the variables were subjected to the $F$ test and regression test. The treatments showed statistical differences in number of fruits per plant, fruit weight (fruit yield) and stem diameter. The highest fruit yield found was $1.36 \mathrm{~kg}_{\text {fruit }}{ }^{1}$ and the highest water use efficiency was $4.08 \mathrm{~g} \mathrm{~mm}^{-1}$ with irrigation for a soil water tension of $10 \mathrm{kPa}$. The lowest fruit yield was found with irrigation for a soil water tension of $50 \mathrm{kPa}$.

Keywords: Cucumismelovar. reticulatus, water deficit, soil water.

\section{Introduction}

Muskmelon (Cucumis melo var. reticulatus Naud.) is a species of the Cucurbitaceae family, whose fruits are netted and have round-oval shape. Commercial crops of this fruit was first implemented in Brazil in 1986, by the Cotia Agricultural Cooperative. This fruit has good commercial prices and can be grown in small areas with good profitability (RIZZO, 1999). Brazil is an exporter of melon of the variety inodorus, which has low sugar content, however, melons of the variety reticulates are preferred, which have higher sugar content and are more visually attractive. Muskmelon fruits of high quality requires special crop conditions, such as a greenhouse, tutoring and adequate conduction and pruning system, however, information on these subjects for the Brazilian conditions are still scarce (MARUYAMA et al., 2000). The main varieties of commercially produced melon (C. melo) are the

\footnotetext{
1 Instituto Federal do Triângulo Mineiro - IFTM, Campus Uberaba, MG, professor-doutor em Irrigação e Drenagem, Bolsista PET MEC. marciosantana@iftm.edu.br

2 Instituto Federal do Triângulo Mineiro - IFTM, Campus Uberaba, MG, tecnólogo em Irrigação e Drenagem. guilherme-cstid@hotmail.com

3 Instituto Federal do Triângulo Mineiro - IFTM, Campus Uberaba, MG, engenheiro agrônomo. murilo sgobi@hotmail.com

4 Universidade Estadual Paulista "Júlio de Mesquita Filho", Campus Jaboticabal, SP, engenheira agrônoma, doutoranda em Produção Vegetal. taynarabvaleriano@gmail.com

5 Universidade Estadual Paulista "Júlio de Mesquita Filho", Campus Jaboticabal, SP, engenheira agrônoma, doutoranda em Produção Vegetal.stefany_souzakz@hotmail.com
} 
inodorus (odorless melons) and cantaloupensis and reticulates (aromatic melons). Fruits of the variety inodorus have smooth or slightly wrinkled peel and yellow, white or dark green coloration. Fruits of the varieties cantaloupensis and reticulatus have netted, warty or scaly surface and pulp with characteristic aroma and orange, salmon or green coloration (MENEZES et al., 2000).

Melon is the most exported product among fruits and vegetables in Brazil (Agrianual, 2013). According to Melo et al. (2014), the growing demand for melon has expanded producing areas and differentiated the market of this fruit in Brazil, and despite the predominant consumption of yellow melon, consumption of muskmelon is gradually increasing due to the quality of these fruits.

However, the lack of specific information on appropriate timing and water requirement for irrigation of this crop is one of the difficulties faced by producers. Moreover, irrigation is usually based on empirical irrigation practices, which can increase production costs and decrease fruit yield. Thus, information on the response of different cultivars to water deficit, especially in phenological periods of greater water demand, is essential to the crop planning and efficient management of irrigation systems (LIBARDI, 1996).

According to Silva et al. (2004), total water consumption accumulated by melon up to 80 days after transplanting is $101 \mathrm{~L}$ for fertilized plants and $26 \%$ lower without fertilizer applications.

The period of greatest water demand by melon crops is from the development of branches to beginning of fruiting (PINTO et al., 1994). Excess water in the maturation period negatively affects the quality of fruits (CARON; HELDWEIN, 2000). Soil moisture can affect yield and quality of melon fruits (SIQUEIRA et. al, 2009).

Melon requires moderate amount of water in the soil from germination to initial development. More frequent irrigations are recommended when the plants begin to emit lateral branches, flowering and beginning of fruiting, which is the period of greater demand of water by the plants. During this period, producers from the Northwest region of Brazil use daily irrigation with two shifts (SOUSA et. al., 2000).

Tensiometry can be used for an adequate irrigation management, by determining the optimal tension for irrigation, which varies with crop, cultivar, type of soil and local climate, establishing the adequate water depth to be applied. Due to the lack of information on optimal tensions for irrigation, producers and researchers use averages found in the literature. Pires et al. (2013) used irrigation for a soil water tension below $30 \mathrm{kPa}$ and found that it was sufficient for the melon; they found a lower water demand at the vegetative development stage followed by a substantial increase at the flowering and fruiting stages. However, according to Doorenbos e Pruitt (1977), the soil water tension for melon crops must be between 30 and $80 \mathrm{kPa}$.

In this context, the objective of this work was to determine the soil water tension that promotes the greatest fruit yield of muskmelon crops.

\section{Material and methods}

The experiment was conducted in a greenhouse located in the experimental area in the olericulture sector of the Federal Institute of Education, Science and Technology of Triângulo Mineiro, Uberaba Campus, State of Minas Gerais, Brazil (19³9'19"S, 47057'27"W and altitude of $800 \mathrm{~m}$ ). The soil from the experimental area was classified as a distroferric Red Latosol (Oxisol), whose physical characteristics were evaluated in the Laboratory of Soil Analysis of Empresa de Pesquisa Agropecuária de Minas Gerais (EPAMIG) - Uberaba (Table 1). 
Table 1. Soil physical characteristics of the experimental area

\begin{tabular}{ccccc}
\hline \multirow{2}{*}{ Layer $(\mathbf{c m})$} & Sand & Silt & Clay & \multirow{2}{*}{ Textural class } \\
\cline { 2 - 4 } & & $(\%)$ & & \\
\hline $0-20$ & 70 & 11 & 19 & Sandy loam \\
$20-40$ & 68 & 12 & 20 & Sandy loam \\
\hline
\end{tabular}

Source: Elaborated by the authors

The equations for fitting soil water retention curves of the soil layers $0-20$ and 20-40 cm, according to Genuchten (1980) model, are shown in Table 2. The mean soil density by the Uhland cylinder method were $1.0 \mathrm{~g} \mathrm{~cm}^{-1}$ (layer $0-20 \mathrm{~cm}$ ) and $1.09 \mathrm{~g} \mathrm{~cm}^{-1}$ (layer $20-40 \mathrm{~cm}$ ).

Table 2. Soil water characterization of the experimental area

\begin{tabular}{|c|c|c|}
\hline Layer $(\mathrm{cm})$ & Equation & $\mathbf{R}^{2}$ \\
\hline $0-20$ & $\theta=\frac{0,46}{\left[1+\left(1.4 * \psi_{m}\right)^{4.707}\right]^{0.116}}+0.078$ & 0.925 \\
\hline $20-40$ & $\theta=\frac{0,375}{\left[1+\left(0.985 * \psi_{m}\right)^{6.917}\right]^{0.127}}+0.238$ & 0.958 \\
\hline
\end{tabular}

$\theta=$ Volumetric moisture $\left(\mathrm{cm}^{3} \mathrm{~cm}^{-3}\right) ; \psi_{\mathrm{m}}=$ Matric potential $(\mathrm{kPa})$

Source: Elaborated by the authors

Muskmelon seeds were sowed in polystyrene trays. Seedlings were transplanted to the field 25 days later, to a total cycle of 105 days. The hybrid Bonus-N2 was used for the experiment. Fertilization followed the recommendations of Comissão de Fertilidade do Solo do Estado de Minas Gerais (CHAGAS et al., 1999), with five top dressings. Thiophanate-methyl fungicides were applied during the experiment.

A randomized block experimental design was used with five treatments (soil water tensions of 10, 20, 30, 40 and $50 \mathrm{kPa}$ ) and four replications. Each experimental plot consisted of 2 rows of 14 plants. Data were collected from the 2 (two) central plants of the plots.

A drip irrigation system was used, with in-line emitters inserted into the drip tubing, spaced $0.60 \mathrm{~m}$ apart (one emitter per plant). The water depths were determined using tensiometry.

The soil moisture contents were calculated using the observed soil water tensions, based on the curve of the layer $0-20 \mathrm{~cm}$. The percentage of wetted area was considered for the irrigation water depth. The water depths to be applied were calculated using these data of moisture and field capacity, considering the muskmelon root system depth, using the equations 1, 2 and 3

$$
\begin{aligned}
& N W D=\left(\theta_{c c}-\theta_{\text {actual }}\right) * z \\
& G W D=N W D / E a \\
& G W D_{\text {mean }}=G W D_{10}
\end{aligned}
$$

at which NWD is the net water depth $(\mathrm{mm}) ; \theta_{c c}$ is the moisture at field capacity $\left(\mathrm{cm}^{3} \mathrm{~cm}^{-3}\right) ; \theta_{\text {actual }}$ is the moisture at irrigation $\left(\mathrm{cm}^{3} \mathrm{~cm}^{-3}\right) ; z$ is the root system depth $(\mathrm{mm})$; GWD is the gross water depth $(\mathrm{mm}) ;$; Ea is the system application efficiency $(0,9) ; G W D_{10}$ is the mean water depth obtained by the sensors installed in the field at $0.10 \mathrm{~m}$.

The average fruit weight per plant (fruit yield), stem diameter (45 and 65 days after transplanting) and number of fruits per plant were evaluated. The water use efficiency was evaluated by the correlation between the fruit yield and water depth applied in each treatment. 
The data of all parameters were subjected to analysis of variance, using the distribution test $F$ at $1 \%$ of probability (except for the water use efficiency). Regression analysis was used to compare the means.

\section{Results and discussion}

The water depths applied in the experiment, the average irrigation frequency and the number of irrigations of each treatment are shown in Table 3.

Caron and Heldwein (2000) evaluated the water consumption by melon crops and found 209.6 $\mathrm{mm}$ in 15 weeks in 1996 (average daily consumption of $1.9 \mathrm{~mm}$ ), 166.8mm in 14 weeks in 1997 (average daily consumption of $1.7 \mathrm{~mm}$ ) and $159.1 \mathrm{~mm}$ in 17 weeks in 1998 (average daily consumption of $1.3 \mathrm{~mm})$.

Table 3. Water depths applied and number of irrigations as functions of soil water tensions

\begin{tabular}{ccccc}
\hline $\begin{array}{c}\text { Treatments } \\
(\mathbf{k P a})\end{array}$ & $\begin{array}{c}\text { Water depths } \\
\text { applied for the } \\
\text { treatments }(\mathbf{m m})\end{array}$ & $\begin{array}{c}\text { Total Water depths } \\
(\mathbf{m m})\end{array}$ & $\begin{array}{c}\text { Irrigation frequency } \\
\text { (days) }\end{array}$ & $\begin{array}{c}\text { Number of } \\
\text { irrigations }\end{array}$ \\
\hline 10 & 275.93 & 332.96 & 1.0 & 63 \\
20 & 247.80 & 303.80 & 1.4 & 45 \\
30 & 138.86 & 195.86 & 3.3 & 19 \\
40 & 116.53 & 173.53 & 4.8 & 13 \\
50 & 119.06 & 176.06 & 5.2 & 12 \\
\hline
\end{tabular}

Source: Elaborated by the authors

The soil water tensions were collected during the experimental period (Figure 1), and their averages used to perform the irrigations of the treatments $10,20,30,40$ and $50 \mathrm{kPa}$, which were respectively $17.93 ; 22.91$; $36.21 ; 46.61$ and $58.91 \mathrm{kPa}$.

Figure 1. Soil water tension of the treatments during the experiment

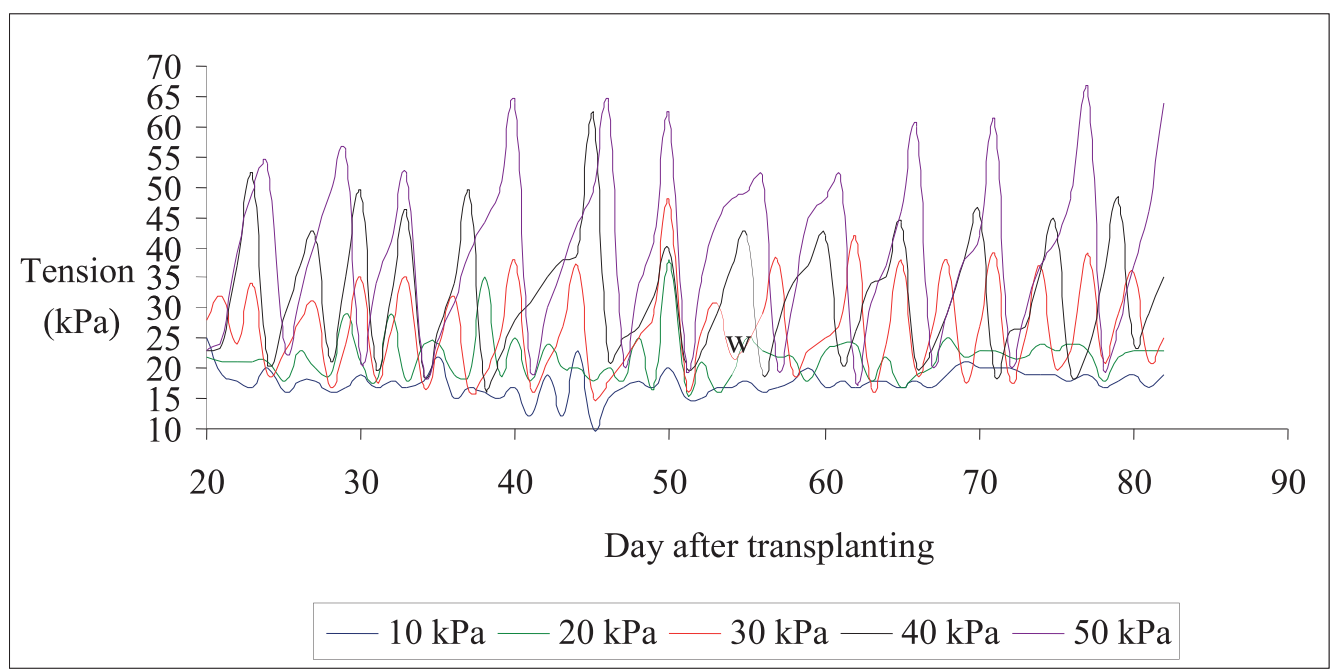

Source: Elaborated by the authors

The fruit number per plant, fruit weight (fruit yield) and stem diameter (in both evaluations) of the treatments showed statistical differences at $5 \%$ probability by the $F$ test. All variables evaluated were negatively affected by increasing soil water tension (Figures 2, 3 and 4). The highest number of fruits per plant (2.0) and average fruit weight per plant (1.36 kgfruit $\left.^{-1}\right)$ were found with daily irrigations to reach the soil field capacity. Negative effects of increasing soil water tension on these varia- 
bles were also found on other species (SANTOS, 2002; SANTOS; PEREIRA, 2004). Filgueira (2000) recommended more frequent irrigations during the flowering and beginning of fruiting stage, which is the period of greater water demand by muskmelon.

According to Silva and Marouelli (1998), the maximum soil water tension, at which the crop responds with optimum fruit yield, is around $30 \mathrm{kPa}$. However, Sousa et al. (1999) recommend irrigation for melon crops when the soil water tension is between $6 \mathrm{kPa}$ and $15 \mathrm{kPa}$ at $30 \mathrm{~cm}$ depth. Araújo et al. (2010) evaluated irrigation of melon using class A tanks and found an increasing linear fruit yield with increasing irrigation rates, resulting in the maximum fruit yield of $4 \mathrm{~kg} \mathrm{~m}^{-2}$, and improvement of fruit physical characteristics (except pulp firmness) with increasing irrigation depths. Braga et al. (2006) recommended irrigation for melon crops when the soil water tension is between 30 and $40 \mathrm{kPa}$.

Water management is undoubtedly one of the factors that require more care in melon crops. Symptoms of water deficit in plants are shown in different forms and intensities, and can become the main cause for decreasing fruit yield. On the other hand, there are soil moisture limits for good vegetative development. The ideal soil water content varies according to various factors, but mainly to the crop development stage (BRANDÃO FILHO;VASCONCELLOS, 1998).

Figure 2. Number of fruits as a function of soil water tensions

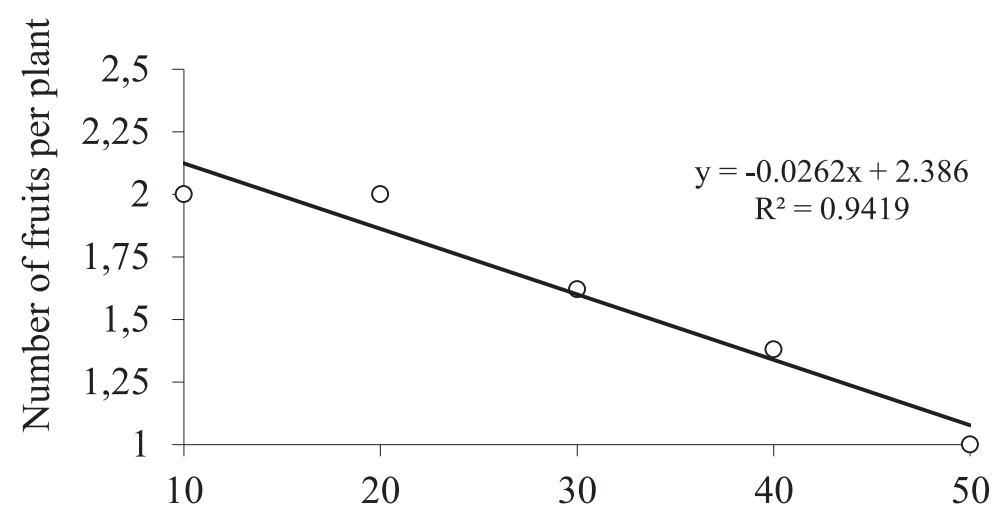

Soil water tension $(\mathrm{kPa})$

Source: Elaborated by the authors

Figure 3. Fruit yield (average fruit weight) as a function of soil water tensions

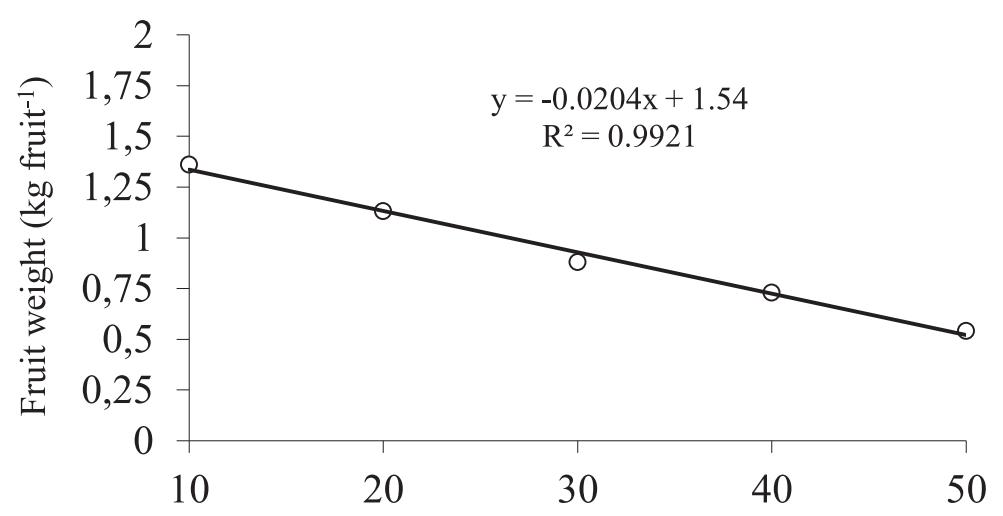

Soil water tension $(\mathrm{kPa})$

Source: Elaborated by the authors 
Figure 4. Stem diameter as a function of soil water tensions

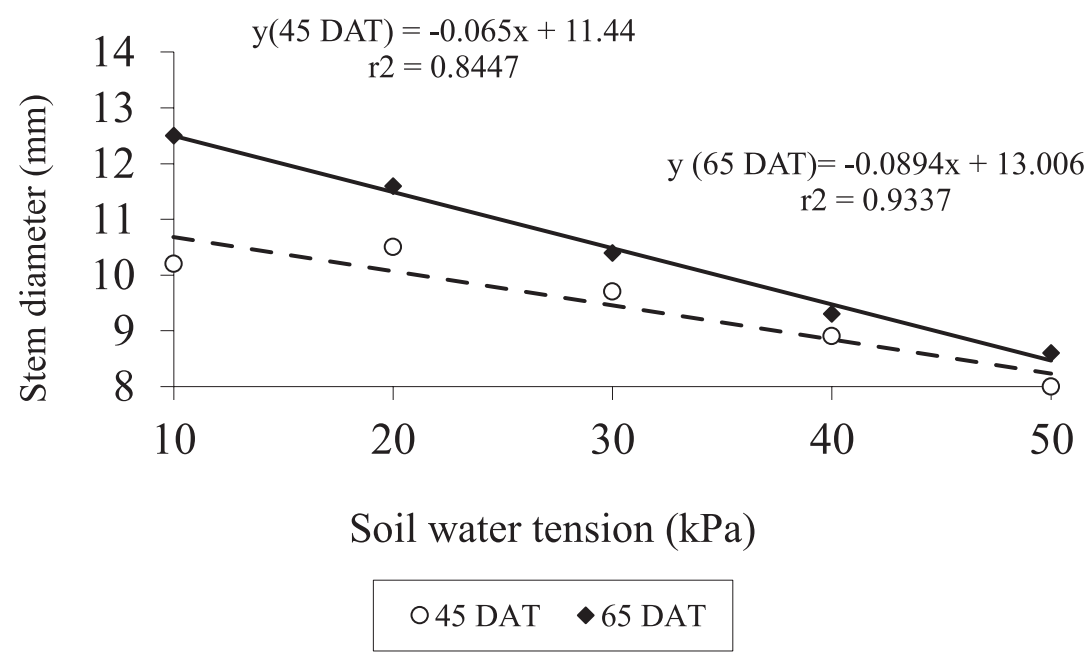

Source: Elaborated by the authors

The largest water use efficiency as a function of soil water tension was found with irrigation performed daily (10 kPa) (Table 4), denoted by the high fruit yield achieved with this treatment in comparison with the others. According to Azevedo et al. (2005), water excess can reduce oxygen in the root zone, hindering the plant respiration and, consequently, reducing energy production needed for synthesis and translocation of organic compounds and their absorption. In addition, water excess can leach nutrients, reducing their availability to plants. On the other hand, the water deficit can markedly reduce physiological activities, especially cell division and growth, decreasing the plant growth. Moreover, water deficit may cause closure of stomata, decreasing cellular concentration of $\mathrm{CO}_{2}$ by decreasing its assimilation, reducing the plant production.

Table 4. Water use efficiency as a function of soil water tensions

\begin{tabular}{cc}
\hline $\begin{array}{c}\text { Soil water tension } \\
(\mathrm{kPa})\end{array}$ & $\begin{array}{c}\text { Water use efficiency } \\
\left(\mathrm{g} \mathrm{mm}^{-1}\right)\end{array}$ \\
\hline 10 & 4.08 \\
20 & 3.35 \\
30 & 3.77 \\
40 & 3.68 \\
50 & 3.91 \\
\hline
\end{tabular}

Source: Elaborated by the authors

\section{Conclusions}

The fruit number per plant, fruit yield and stem diameter of the muskmelon crops were negatively affected by increasing soil water tension. The highest fruit yield was found in the treatment with soil water tension of $10 \mathrm{kPa}$ (average of $17.93 \mathrm{kPa}$ ), in which larger fruits were produced and in greater quantity.

Soil water tensions above $20 \mathrm{kPa}$ decrease yield and quality of muskmelon fruits, probably due to the water stress. The highest water use efficiency in the muskmelon crops was found in the treatment with soil water tension of $10 \mathrm{kPa}$. 


\section{Resumo}

O cultivo e o consumo do melão rendilhado vêm aumentando (MELO et al., 2014), sendo necessário o conhecimento de técnicas para seu melhor cultivo em campo. 0 atual experimento foi conduzido no IFTM Campus Uberaba (MG), com objetivo de avaliar a produtividade do melão rendilhado submetido a tensões de água no solo. 0 delineamento experimental foi em blocos casualizados com cinco tratamentos (momento de irrigar com tensões de $10 \mathrm{kPa}, 20 \mathrm{kPa}, 30 \mathrm{kPa}, 40 \mathrm{kPa}$ e $50 \mathrm{kPa}$ ) e quatro repetições (duas linhas de plantio com 14 plantas). Foram realizadas duas colheitas e estimada a produtividade da cultura. Determinaram-se o diâmetro de caule, o número de frutos e a eficiência do uso da água. A irrigação foi realizada por gotejamento e o manejo por tensiometria. A cultivar utilizada foi a Bônus n.2, em espaçamento de 1,0 x 0,60 m. Os dados das variáveis avaliadas foram submetidos ao teste $\mathrm{F}$ e posteriormente ao teste de regressão. Houve diferença estatística entre os tratamentos para o número de frutos, o peso dos frutos (produtividade) e o diâmetro do caule. Pôde-se concluir que a maior produtividade estimada foi de 1,36 $\mathrm{kg}_{\text {fruto-1 }}$ e a maior eficiência do uso da água foi de 4,08 $\mathrm{g} \mathrm{mm}^{-1}$, quando a irrigação foi efetuada a $10 \mathrm{kPa}$. A menor produtividade foi verificada quando a irrigação foi efetuada com tensão de $50 \mathrm{kPa}$. Palavras-chave: Cucumis melo var. reticulatus, déficit hídrico, água no solo.

\section{Referências}

Agrianual 2013: anuário da agricultura brasileira. São Paulo: FNP Consultoria \& Agroinformativo, 2013.

ARAÚJO, W. F.; OLIVEIRA, G. A.; CARVALHO, F. K.; SILVA, W. M.; CRUZ, P. L. S.; MACIEL, F. C. S. Manejo da irrigação do meloeiro com base na evaporação do tanque classe A. Horticultura Brasileira, v. 28, n. 4, p. 495-499, 2010. Disponível em: <http://www.scielo.br/pdf/hb/v28n4/20. pdf>. Acesso em: 02 mar. 2016.

AZEVEDO, B. M.; BASTOS, F. G. C.; VIANA, T. V. A.; RÊGO, J. L.; D’AVILA, J. H. T. Efeitos de níveis de irrigação na cultura da melancia. Revista Ciência Agronômica, v. 36, n. 1, p. 9-15, 2005. Disponível em: <http://www.ccarevista.ufc.br/seer/index.php/ccarevista/article/view/4061/1057>. Acesso em: 10 mar. 2016.

BRAGA, M. B. B.; DUENHAS, L. H.; SOUZA, C. M. P.; KLAR, A. E. Orientação geográfica de estufas de polietileno e potenciais de água no solo no cultivo do melão rendilhado híbrido "Nero". Irriga, v. 11, p. 130-138. 2006. Disponível em: <https://www.infoteca.cnptia.embrapa.br/bitstream/ doc/157302/1/OPB673.pdf>. Acesso em: 10 fev. 2016.

BRANDÃO FILHO, J. U. T.; VASCONCELLOS, M. A. S. A cultura do meloeiro. In: GOTO, R.; TIVELLI, S. W. (org). Produção de hortaliças em ambiente protegido: condições subtropicais. São Paulo: FUNEP, 1998, p. 161-193.

CARON, B. O.; HELDWEIN, A. B. Consumo d'água e coeficiente de cultura para o meloeiro cultivado em estufa plástica na primavera. Revista Bras. Agrometeorologia. v. 8, n. 1, p. 19-25, 2000.

CHAGAS, J. M.; BRAGA, J. M.; VIEIRA, C.; SALGADO, L. T.; JUNQUEIRA NETO, A.; ARAÚJO, G. A. A.; ANDRADE, M. J. B.; LANA, R. M. Q.; RIBEIRO, A. C. Recomendação adubação para o feijão. In: RIBEIRO, A. C.; GUIMARÃES, P. T.; ALVAREZ, V. H. Recomendações para o uso de corretivos e 
fertilizantes em Minas Gerais. Viçosa: Comissão de fertilidade do solo do estado de Minas Gerais, 1999. p. 306-308.

DOORENBOS, J.; PRUITT, W. O. Guidelines for predicting crop water requirements. Rome: FAO, 179p., 1977. (FAO: Irrigation and Drainage Paper, 24).

FILGUEIRA, F. A. R. Novo manual de Olericultura: Agrotecnologia moderna na produção e comercialização de hortaliças. Viçosa: UFV, 2000.

GENUCHTEN, M. T. A closed-form equation for predicting the hydraulic conductivity of unsaturated soils. Soil Science Society American Journal, Madison, v. 50, p. 288-91, 1980.

LIBARDI, V. C. M. Efeitos de diferentes níveis de irrigação e do déficit hídrico na produção do feijoeiro. 1996. 49 p. Dissertação (Mestrado em Agronomia) - Escola Superior de Agricultura "Luiz de Queiroz", Universidade de São Paulo, Piracicaba, 1996.

MARUYAMA, W. I.; BRAZ, L. T.; CECÍLIO FILHO, A. B. Condução de melão rendilhado sob cultivo protegido. Horticultura Brasileira, Brasília, v. 18, n. 3, p. 175-178, 2000.

MENEZES, J. B.; FILGUEIRAS, H. A. C.; ALVES, R. E.; MAIA, C. E.; ANDRADE, G. G.; ALMEIDA, J. H. S.; VIANA, F. M. P. Característica do melão para exportação. In: ALVES, R. E. (Org.) Melão: pós-colheita. Fortaleza: Embrapa Agroindústria Tropical, 2000. p. 13-22.

MELO, D. M.; CHARLO, H. C. O.; CASTOLDI, R.; BRAZ, L. T. Dinâmica do crescimento do meloeiro rendilhado 'Fantasy' cultivado em substrato sob ambiente protegido. Biotemas, v. 27, p. 19-29. 2014. Disponível em: <https://periodicos.ufsc.br/index.php/biotemas/article/view/2175-7925.2014v27n2p19>. Acesso em: 20 fev. 2016.

PINTO, J. M.; SOARES, J. M.; PEREIRA, J. B.; CHOUDHURY, E. N.; CHOUDHURY, M. M. Efeito do período e freqüências da fertirrigação na produção do melão. Pesquisa Agropecuária Brasileira, Brasília, v. 29, n. 9, p. 1345-1350, 1994.

PIRES, M. M. M. L.; SANTOS, H. A.; SANTOS. D. F.; VASCONCELOS, A. S.; ARAGÃO, C. A. Produção do meloeiro submetido a diferentes manejos de água com uso de manta de tecido não tecido. Horticultura Brasileira, Brasília, v. 31, p. 304-310, 2013.

RIZZO, A. A. N. Avaliação de caracteres agronômicos e qualitativos de cinco cultivares de melão rendilhado (Cucumis melo var. reticulatus Naud.) e da heterose em seus híbridos F1. 1999. $59 \mathrm{f}$. Dissertação (Mestrado em Agronomia) - Faculdade de Ciências Agrárias e Veterinárias, Universidade Estadual Paulista, Jaboticabal, 1999.

SANTOS, D. S. dos. Efeitos da tensão de água no solo, na cultura do pepino (Cucumis sativus L.), utilizando sistema de irrigação automatizado. 2002. 60 f. Dissertação (Mestrado em Irrigação e Drenagem) - Universidade Federal de Lavras, Lavras, 2002.

SANTOS, S. R.; PEREIRA, G. M. Comportamento da alface tipo Americana sob diferentes tensões da água no solo, em ambiente protegido. Revista Engenharia Agrícola. Jaboticabal, SP, v. 24, n. 3, p. 569-577, 2004. 
SILVA, W. L. C.; MAROUELLI, W. A. Manejo da irrigação em hortaliças no campo e em ambientes protegidos. In: FARIA, M. A.; SILVA, E. L.; VILELA, L. A. A.; SILVA, A. M. (Ed.). Manejo de irrigação. Lavras: UFLA/SBEA, 1998. p. 311-348.

SILVA, T. J. A.; MACHADO, C. C.; BONFIM-SILVA, E. M.; COELHO, R. D. Coeficiente de cultivo (Kc) do meloeiro tipo rendilhado cultivado em ambiente protegido. Irriga, Botucatu, v. 9, n. 1, p. 72-81, jan/abr. 2004.

SIQUEIRA, W. C.; FARIA, L. A.; LIMA, E. M. C.; REZENDE, F. C.; GOMES, L. A. A.; CUSTÓDIO, T. N. Qualidade de frutos de melão amarelo cultivado em casa de vegetação sob diferentes lâminas de irrigação. Ciência agrotecnológica, Lavras, v. 33, n. 4, p. 1041-1046, jul./ago. 2009.

SOUSA, V. F.; RODRIGUES, B. H. N.; ATHAYDE SOBRINHO, C.; COELHO, E. F.; VIANA, F. M. P.; SILVA, P. H. S. Cultivo do meloeiro sob fertirrigação por gotejamento no meio-norte do Brasil. Teresina: Embrapa Meio-Norte, 1999. 68p (Circular Técnica, 21).

SOUSA, V. F. de; COELHO, E. F.; ANDRADE JUNIOR, A. S. de; FOLEGATTI, M. V.; FRIZZONE, J. A. Eficiência do uso da água pelo meloeiro sob diferentes freqüências de irrigação. Revista Brasileira de Engenharia Agrícola e Ambiental, Campina Grande, v. 4, n. 2, p. 183-188, 2000.

\section{Histórico editorial:}

Submetido em: 14/03/2016

Aceito em: 12/08/2016

Como citar:

ABNT

SANTANA, M. J. de; BOCATE, G. A.; SGOBI, M. A.; VALERIANO, T. T. B.; SOUZA, S. S. de. Irrigation management of muskmelon with tensiometry. Revista Agrogeoambiental, Pouso Alegre, v. 9, n. 3, p. 71-79, jul./set. Doi: http://dx.doi.org/10.18406/2316-1817v9n32017965

$\underline{A P A}$

SANTANA, M. J. de, BOCATE, G. A., SGOBI, M. A., VALERIANO, T. T. B. \& SOUZA, S. S. de. (2017). Irrigation management of muskmelon with tensiometry. Revista Agrogeoambiental, Pouso Alegre, 9 (3), 71-79.

Doi: http://dx.doi.org/10.18406/2316-1817v9n32017965

$\underline{\text { ISO }}$

SANTANA, M. J. de; BOCATE, G. A.; SGOBI, M. A.; VALERIANO, T. T. B. e SOUZA, S. S. de. Irrigation management of muskmelon with tensiometry. Revista Agrogeoambiental, 2017, vol. 9, n. 3, pp. 71-79.

Eissn 2316-1817. Doi: http://dx.doi.org/10.18406/2316-1817v9n32017965

\section{VANCOUVER}

Santana MJ de, Bocate GA, Sgobi MA, Valeriano TTB, Souza SS de. Irrigation management of muskmelon with tensiometry. Rev agrogeoambiental. 2017 jul/set; 9(3): 71-79.

Doi: http://dx.doi.org/10.18406/2316-1817v9n32017965 